\title{
KEPADATAN PERMUKIMAN DAN KETERSEDIAAN RUANG BERMAIN ANAK
}

\author{
Parmonangan Manurung \\ Program Studi Teknik Arsitektur Fakultas Arsitektur dan Desain \\ Universitas Kristen Duta Wacana \\ Gedung Agape lantai 5, Jl. Dr. Wahidin 5-25 Yogyakarta \\ *Email: monang@staff.ukdw.ac.id
}

\begin{abstract}
ABSCTRACT
The growth rate of people very rapidly with urbanization and density urban environments, had affected the availability of children's playground in informal settlements, especially in big cities. These conditions have adverse effects for the development of children who live in urban environments. Children as mandated by law, have the right to get a chance to play, on the other hand, play a part of the development of the child as well as a medium of learning. Base on this background, this paper aims to examine the influences of density informal settlements in urban environment for the availability of children's playground, especially friendly playground. This paper used qualitative research methods to conduct a literature study and observation to some locations where children play. The results showed that the density of settlement and urban growth over time reduces children's playground, and this will have an impact on the growth and development of children. From the discussion, it can be concluded that, an open space or a children-friendly playground in an informal settlement is needed in order to support the growth and development of children, because play is a very important activity in the process of their physical growth and social development.
\end{abstract}

Keywords: urban density, informal settlement, playground, children.

\section{PENDAHULUAN}

Berdasarkan data Badan Pusat Statistik (BPS), tahun 2010 dan 2015 jumlah penduduk Indonesia berusia $0-14$ memiliki persentase sebesar $28,6 \%$ dan $27,3 \%$ dari total penduduk Indonesia. Pada tahun 2010 dan 2015 penduduk Indonesia mencapai 238,5 dan 255,5 juta jiwa. Data ini menunjukkan jumlah anak-anak di Indonesia sangat signifikan mencapai tujuh puluh juta jiwa pada tahun 2015 .

Pertumbuhan penduduk Indonesia yang sangat pesat tersebar secara tidak merata, sebagian besar penduduk Indonesia tinggal di perkotaan. Sebagaimana data Perserikatan Bangsa-Bangsa tahun 2014 yang mengatakan bahwa pada tahun 2014 penduduk Indonesia yang tinggal di perkotaan mencapai lebih dari lima puluh persen. Sumber yang sama memprediksi pada tahun 2050, Indonesia akan menjadi negara peringkat ke lima terbesar dalam jumlah penduduk yang tinggal di perkotaan, yaitu mencapai 134 juta jiwa. Tingginya jumlah penduduk yang tinggal di perkotaan berdampak pada ketersediaan ruang terbuka publik di perkotaan sebagaimana disampaikan Dewiyanti (2011) yang mengatakan bahwa pemanfaatan lahan untuk pembangunan berbagai fasilitas perkotaan berdampak pada berkurangnya lahan bagi ruang terbuka publik.

Dari data di atas dapat disimpulkan bahwa pertumbuhan penduduk yang sangat pesat di Indonesia berdampak pada terjadinya perpindahan penduduk dari desa ke kota sehingga sebagian besar penduduk Indonesia tinggal di perkotaan. Hal ini berdampak pada ketersediaan ruang terbuka publik. Kurangnya ruang terbuka publik akan mengakibatkan berkurangnya ruang bermain anak di perkotaan, padahal di sisi lain jumlah anak-anak di Indonesia hampir mencapai $30 \%$ dari total penduduk Indonesia.

\section{METODE PENELITIAN}

Metode penelitian yang digunakan adalah kualitatif dengan melakukan pengamatan langsung di lapangan untuk mendapatkan data 
tentang kepadatan dan kondisi permukiman informal, ruang terbuka dan lokasi-lokasi ruang bermain anak di permukiman padat penduduk di kota Yogyakarta. Pengamatan dilakukan pada empat permukiman padat penduduk di empat kelurahan yaitu, Kel. Pakuncen, Kel. Cokrodiningrat, Kel. Prawirodirjan, dan Kel. Klitren. Ke empat kelurahan tersebut berada di empat kecamatan berbeda. Ke empat permukiman tersebut dipilih karena berada di pusat kota dan memiliki tingkat kepadatan yang tinggi. Selain itu, keempat lokasi juga memiliki karakter yang berbeda berdasarkan letaknya yaitu di tepian sungai, di kawasan komersial, dan di tepi rel kereta. Pengumpulan data dilakukan dengan merekam kondisi eksisting menggunakan kamera, melakukan wawancara dengan orang tua/pengasuh dan dengan anakanak yang bermain. Data kondisi eksisting permukiman dikumpulkan untuk melihat tingkat kepadatan permukiman pada tiap-tiap lokasi amatan. Waktu pengamatan dan pengumpulan data di lapangan disesuaikan dengan kebutuhan data. Untuk mendapatkan data visual tentang kondisi eksisting permukiman, pengamatan dilakukan pada hari biasa baik pagi maupun sore hari, sementara untuk mendapatkan data tentang kegiatan bermain anak dan lokasi yang digunakan anak, pengamatan dilakukan pada hari libur saat anak-anak bermain. Analisis dilakukan dengan membandingkan data di lapangan dengan teori terkait. Hasil analisis kemudian disimpulkan untuk menjadi sebuah temuan dan rekomendasi.

\section{HASIL DAN PEMBAHASAN}

\section{Kepadatan permukiman}

Pertumbuhan penduduk di Indonesia berdampak pada kepadatan permukiman di perkotaan sebagai akibat dari urbanisasi. Kondisi ini seringkali tidak diimbangi dengan pembangunan fasilitas pendukung. Tidak meratanya pembangunan infrastruktur dasar mengakibatkan terjadinya kepadatan penduduk di beberapa kawasan perkotaan (Suhaeni, 2010). Lebih lanjut Suhaeni mengatakan bahwa pesatnya pertambahan penduduk sering kali tidak disertai dengan sarana dan prasarana kota yang memadai. Dengan kata lain dapat disimpulkan bahwa fasilitas perkotaan belum mampu memenuhi kebutuham warganya. Keberadaan sarana dan prasarana kota sangat dibutuhkan masyarakat termasuk ruang terbuka publik sebagai fasilitas yang mewadahi berbagai aktifitas warga kota. Kurangnya ruang terbuka publik termasuk ruang bermain anak sebagaimana telah dipaparkan di bagian Pendahuluan terlihat pada lokasi yang menjadi obyek amatan.

Tingkat kepadatan kota berpengaruh pada kepadatan permukiman di perkotaan akibat semakin terbatasnya lahan perkotaan. Menurut Suhaeni, 2010, dampak kepadatan permukiman selain berpengaruh pada Pemerintah juga berpengaruh pada penduduk karena masyarakat membutuhkan interaksi sosial. Kepadatan permukiman mengakibatkan berkurangnya ruang terbuka dan bahkan halaman bagi sebagian besar rumah warga. Hasil penelitian Suhaeni (2010) di salah satu permukiman padat penduduk di Kelurahan Jamika, Kecamatan Bojongloa Kaler, Bandung, menunjukkan 65\% rumah warga tidak memiliki halaman dengan lebar jalan hanya 1 meter. Kondisi ini banyak terjadi di permukiman di kota-kota besar di Indonesia termasuk lokasi amatan yang berada di kota Yogyakarta.

Hasil pengamatan di ke empat lokasi menunjukkan tingkat kepadatan bangunan yang sangat tinggi pada permukiman penduduk, beberapa lokasi hanya dapat diakses dengan kendaraan roda dua karena lebar gang yang tersedia hanya satu meter. Beberapa lokasi amatan lain yang berada di tepian sungai menunjukkan kondisi lahan berkontur sehingga hanya dapat diakses melalui tangga dengan lebar kurang dari satu meter.

\section{Kurangnya ruang bermain anak}

Kurangnya ruang terbuka publik sebagai area bermain juga diakibatkan karena ruang terbuka akan lebih menguntungkan secara ekonomi bila dijual dibandingkan difungsikan sebagai ruang bermain anak (Wonoseputro, 2007). Apa yang disampaikan Wonoseputro menunjukkan bahwa fasilitas komersil telah menggeser keberadaan area bermain anak karena dianggap lebih menguntungkan secara ekonomi. Faktor-faktor ini menjadi salah satu penyebab berkurangnya ruang terbuka publik yang berfungsi sebagai ruang bermain anak di perkotaan. Kondisi ini tentu sangat memprihatinkan karena ruang bermain anak di ruang publik sangat dibutuhkan anak-anak dalam pertumbuhan dan perkembangan mereka. Keberadaan ruang bermain anak di ruang terbuka semakin berkurang dan digantikan wahana wisata fantasi (Wonoseputro, 2007). Wahana wisata fantasi tidak dapat diakses oleh 
seluruh anak karena keberadaannya yang terbatas dan merupakan fasilitas berbayar. Bermain telah menjadi barang mewah yang didapatkan dengan mengeluarkan biaya karena dilakukan di dalam tempat wisata dan tidak terjangkau bagi sebagian besar anak yang berasal dari keluarga kurang mampu.

\section{Bermain merupakan hak anak-anak}

Tidak tersedianya ruang bermain memiliki pengaruh pada tidak terpenuhinya hak anak sebagaimana diamanatkan Undangundang. Undang-undang perlindungan anak menegaskan bahwa bermain sesungguhnya merupakan hak bagi setiap anak sebagaimana diatur dalam Pasal 11 Undang-undang Republik Indonesia Nomor 23 Tahun 2012 Tentang Perlindungan Anak mengatakan "Setiap anak berhak untuk beristirahat dan memanfaatkan waktu luang, bergaul dengan anak yang sebaya, bermain, berekreasi, dan berekreasi sesuai dengan minat, bakat dan tingkat kecerdasannya demi pengembangan diri." Beradasarkan undang-undang tersebut anak-anak memiliki hak untuk mendapatkan kesempatan bermain dan mengembangkan talenta mereka. Keberadaan ruang bermain ini juga merupakan hak anak yang dilindungi undang-undang. Pada Pasal 22 disebutkan bahwa "Negara dan pemerintah berkewajiban dan bertanggung jawab memberikan sarana dan prasarana dalam penyelenggaraan perlindungan anak."

Kondisi yang terjadi di kota-kota besar tidak mencerminkan dijaminnya hak anak akan kesempatan bermain dan tersedianya fasilitas bermain. Ruang-ruang terbuka publik menjadi sangat sulit untuk ditemukan sehingga anakanak tidak memiliki fasilitas bermain sebagaimana diamanatkan undang-undang.

Menurut Dargan et al. (2006), anak-anak belajar melalui kegiatan bermain dalam lingkungan, berbagi ruang, membangun hubungan dan menjalin ikatan dengan tetangga mereka. Hal ini menunjukkan bahwa kegiatan bermain menjadi hal yang sangat penting bagi anak. Pentingnya kegiatan bermain digambarkan oleh Fromberg dan Bergen (2015) sebagai kegiatan yang sama dengan bernafas, kegiatan bermain mengembangkan kemampuan anak dalam menggunakan bahasa, kompetensi sosial, berpikir kompleks serta menyelesaikan masalah secara kreatif.

\section{Anak-anak mencari alternatif ruang bermain}

Hasil pengamatan terhadap empat permukiman padat penduduk di empat kelurahan berbeda di kota Yogyakarta menunjukkan minimnya bahkan tidak tersedianya ruang terbuka publik dan ruang bermain anak. Tingkat kepadatan bangunan yang tinggi menyebabkan sebagian besar rumah tidak memiliki halaman dan di beberapa lokasi akses yang tersedia hanya memiliki lebar 1 meter. Kondisi ini mengakibatkan sebagian besar rumah tidak memiliki halaman sebagai ruang bermain anak. Kondisi yang sama terjadi dalam skala yang lebih besar. Kawasan permukiman tidak memiliki ruang terbuka yang dapat digunakan sebagai ruang bermain anak.

Anak-anak memanfaatkan ruang terbuka terbatas yang tercipta dari gang sempit dan area reruntuhan bangunan di salah satu permukiman padat di Kecamatan Jetis Pasiraman kota Yogyakarta (Gambar 1).

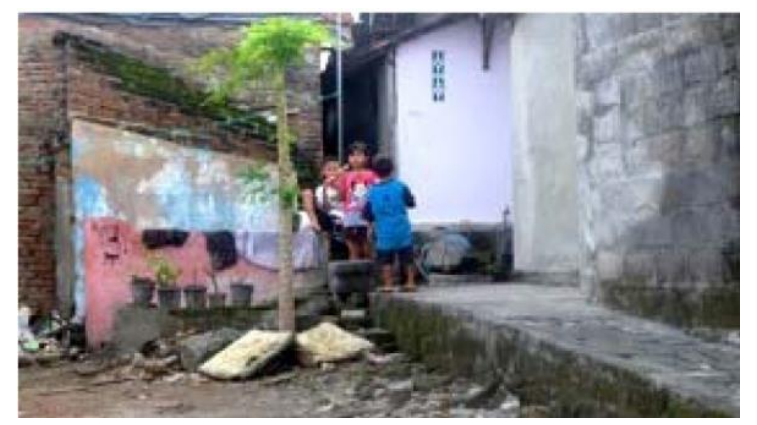

Gambar 1. Anak-anak bermain di antara kepadatan permukiman warga

Akibat terbatasnya ruang bermain dan ruang terbuka yang dapat digunakan sebagai ruang bermain, anak-anak memanfaatkan ruang terbuka yang peruntukkannya bukan sebagai ruang bermain. Kondisi ini terlihat di seluruh lokasi amatan yang terdapat di kecamatan Jetis, kecamatan Wirobrajan dan kecamatan Gondokusuman. Area yang digunakan anakanak sebagai area bermain antara lain adalah area sekitar rel kereta api, jalan (Gambar 2), area tepian sungai dan area bekas reruntuhan bangunan. Kondisi ini tentu sangat membahayakan bagi keselamatan dan keamanan anak-anak. Anak-anak di Kelurahan Prawirodirjan memanfaatkan gang di permukiman mereka sebagai area bermain (Gambar 3). 


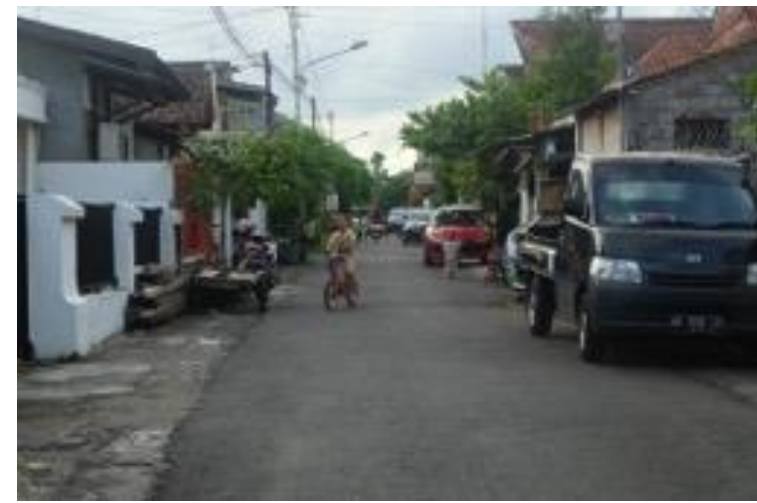

Gambar 2. Jalan Menjadi Salah Satu Area yang Digunakan Anak-Anak Sebagai Area Bermain

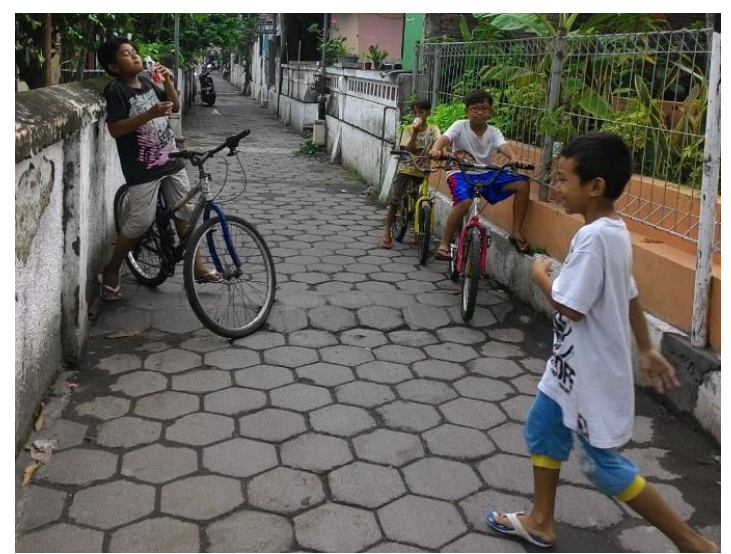

Gambar 3. Gang Sempit Dimanfaatkan AnakAnak sebagai Area Bermain

Hasil pengamatan yang dilakukan pada saat bersamaan berlangsungnya pameran karya instalasi seni mahasiswa Arsitektur Universitas Kristen Duta Wacana di kampung Jetis Pasiraman Kel. Cokrodiningratan (Gambar 4 dan 5) menunjukkan anak-anak sangat antusias memanfaatkan karya instalasi seni sebagai area bermain alternatif. Selama berlangsungnya pameran terlihat hampir seluruh anak di permukiman tersebut memanfaatkan karya instalasi seni sebagai area bermain mereka.

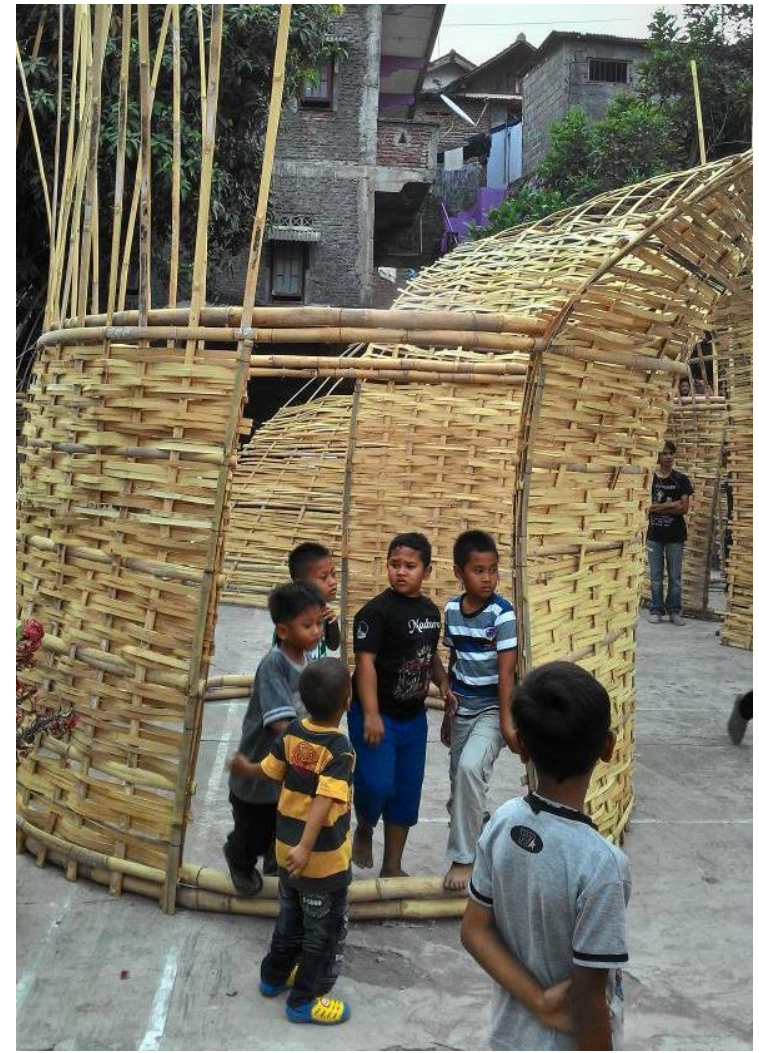

Gambar 4. Karya Instalasi Bambu Mahasiswa Arsitektur UKDW Dimanfaatkan sebagai Area Bermain Alternatif oleh Anak-anak

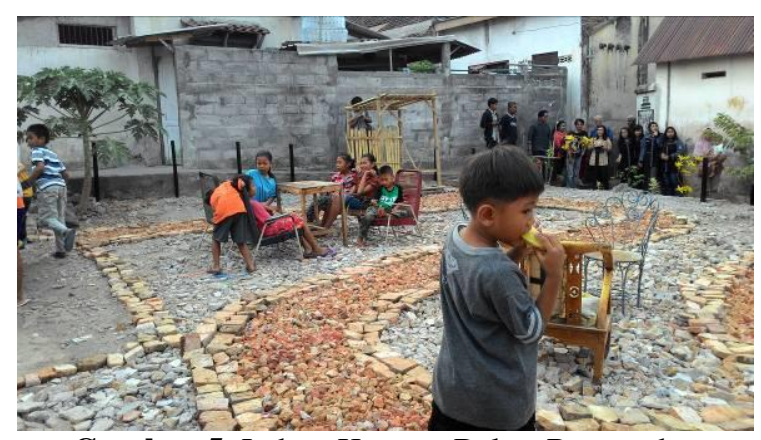

Gambar 5. Lahan Kosong Bekas Reruntuhan

Bangunan yang Digunakan Sebagai Area Instalasi

Seni Dimanfaatkan sebagai Area Bermain oleh Anak-Anak

Hasil pengamatan dan wawancara yang dilakukan setelah berakhirnya pameran instalasi seni di Kel. Cokrodiningratan, menunjukkan anak-anak tidak lagi menggunakan area tersebut sebagai tempat bermain dan sebagian besar anak bermain di jalan sebagaimana mereka lakukan sebelum berlangsungnya kegiatan pameran.

Dari pembahasan ditemukan bahwa akibat padatnya permukiman penduduk anakanak tidak memiliki ruang bermain yang representatifm aman dan nyaman. Kondisi ini membuat mereka mencari ruang lain sebagai alternatif, sebagian besar anak-anak 
mendapatkan ruang bermain di area berbahaya seperti rel kereta api, sungai dan jalan. Untuk menjangkau ruang yang lebih jauh kebanyakan anak-anak bermain sepeda sehingga memungkinkan mereka mengakses ruang yang lebih jauh (Manurung, 2016). Dengan bersepeda anak-anak mampu mencari dan menemukan ruang bermain yang tidak mampu disediakan oleh lingkungan tempat tinggal mereka. Hal ini sangat berbahaya bagi keselamatan anak-anak karena dapat membahayakan jiwa mereka dan jauh dari pengamatan orang tua atau pengasuh.

\section{KESIMPULAN}

Dari hasil pembahasan dapat disimpulkan bahwa kepadatan permukiman di perkotaan sebagai dampak dari pesatnya pertumbuhan penduduk dan urbanisasi telah berakibat pada berkurangnya ruang bermain anak. Kurangnya ruang bermain anak mengakibatkan anak-anak mencari ruang bermain lain yang sering kali merupakan area berbahaya bagi mereka.

Pentingnya ruang bermain anak harus direspon dengan menyediakan ruang bermain ramah anak karena anak merupakan generasi penerus bangsa dan bermain merupakan bagian dari proses belajar anak, terutama pembelajaran menjalin hubungan sosial dan belajar mengenai alam dan lingkungan dan pelajaran lain yang tidak mereka dapatkan di pendidikan formal.

\section{Daftar Pustaka}

Badan Pusat Statistik Proyeksi Penduduk Indonesia Tahun 2010-2035.

Dargan, A., \& Zeitlin, S. (2006) City Play. In Fromberg, D., and Bergen, D., (eds) Play from Birth to Twelve. New York: Tailor and Francis Group, LLC.

Dewiyanti, D. (2011) Ruang Terbuka Hijau Kota Bandung: Suatu Tinjauan Awal Taman Kota Terhadap Konsep Kota Layak Anak. Majalah Ilmiah Unikom Online Bidang Rekayasa, 7 (1) [http://jurnal.unikom.ac.id/volume/vol7].

Fromberg, D.P. \& Bergen, D. (2015) Play from birth to Twelve, Contexts, Perspectives, and Meanings, Third Edition. New York: Routledge.
Manurung, P. (2016) Impact of The Absence or Limitedness of Children Playground on Children Play Activity. Journal of Modern Construction and Architecture, 3 (3), 8-12.

Suhaeni, H. (2010) Tipologi Kawasan Perumahan Dengan Kepadatan Penduduk Tinggi dan Penanganannya. Jurnal Permukiman, 5 (3), 116-123.

Undang-undang Republik Indonesia Nomor 23 Tahun 2002 Tentang Perlindungan Anak.

Wonoseputro, C. (2007) Ruang Publik Sebagai Tempat Bermain Bagi Anak-Anak. Studi Kasus Pengembangan "The Urban Zoo" bagi Kawasan Pecinan di Singapura. Jurnal Dimensi Teknik Arsitektur, 35 (1), 73-79. 